\title{
Pengaruh Kualitas Jasa Dan Nilai Pelanggan Terhadap Minat Kunjungan Ulang Melalui Kepuasan Pasien Di Poli Umum Di RSISA Semarang
}

\section{Influence of Service Quality and Customer Value towards Willingness to Revisit through Patient's Satisfaction at General Polyclinic of Sultan Agung Islam Hospital in Semarang}

\author{
Retno Kusniati, ${ }^{1}$ Naili Farida ${ }^{2}$, Sudiro ${ }^{2}$ \\ 1) FKG UNIMUS Semarang, email: retnok193@yahoo.com \\ 2) Fakultas Ilmu Sosial dan Ilmu Politik, Universitas Diponegoro, Semarang \\ 3) Fakultas Kesehatan Masyarakat, Universitas Diponegoro, Semarang
}

\begin{abstract}
Abstrak
Kepuasan pasien merupakan salah satu indikator dalam menilai mutu pelayanan di rumah sakit. Data jumlah kunjungan total pasien yang fluktuatif dan ada trend penurunan jumlah kunjungan pasien lama di poli umum RSISA Semarang dalam kurun waktu 2010-2013 menunjukan belum optimalnya pelayanan di poli umum. Penelitian ini bertujuan untuk menganalisis secara keseluruhan apakah kualitas jasa dan nilai pelanggan berpengaruh terhadap minat kunjungan ulang melalui kepuasan pasien rawat jalan di poli umum RSISA Semarang.

Penelitian ini merupakan penelitian explanatory, pendekatan waktu cross sectional metode analitik kuantitatif. Populasi penelitian adalah pasien rawat jalan poli umum di RSISA Semarang yang telah berobat minimal 2 kali dengan metode penentuan sampel menggunakan Purposive Sampling. Jumlah sampel sebanyak 125 orang responden. Data dikumpulkan, menggunakan kuesioner dengan item pertanyaan terstruktur dan pengukuran skala Likert 1-5. Pengolahan dan analisis data menggunakan SEM dengan software SmartPLS 2.0.

Hasil penelitian menunjukan bahwa kualitas jasadan nilai pelanggan berpengaruh positif dan signifikan terhadap kepuasan pasien. Kepuasan pasien berpengaruh positif dan signifikan terhadap minat kunjungan ulang. Kepuasan pasien yang dapat dijelaskan oleh kualitas jasa dan nilai pelanggan sebesar $45,3 \%$, sedangkan minat kunjungan ulang pasien yang dapat dijelaskan oleh kepuasan pasien sebesar $45,0 \%$

Kecenderungan penurunan jumlah kunjungan pasien lama disebabkan belum terpenuhi harapan pasien atas pelayanan pasiendi poli umum sehingga kepuasan pasien belum optimal. Manajemen rumah sakit perlu meningkatkan kepuasan pasien dengan selalu memberikan service excellent seperti ketepatan jadwal pelayanan, ketersediaan informasi pelayanan yang tepat, petugas konsisten bersikap sopan, memberi salam, menyapa dan senyum kepada pasien sehingga dapat meningkatkan kepuasan pasien dan meningkatkan pula minat kunjungan ulang pasien berobat di poli umum RSISASemarang.
\end{abstract}

Kata kunci : Kualitas Jasa,Nilai Pelanggan, Kepuasan Konsumen, Minat Kunjungan Ulang Referensi : 13(1996-2015)

\footnotetext{
Abstract

Patient satisfaction is one of the indicators to assessthe quality of hospital services. Number of total patient that fluctuated and also a declining trend of total patient who revisit in general polyclinic of RSISA Semarang from 2010 to 2013 showed that services in general polyclinic was not optimal. The objective of this study was to analyze entirety whether service quality and customer value affect patient's intention to revisit through their satisfaction in general polyclinic of RSISA Semarang.
} 
This study was an explanatory research using cross-sectional approach and quantitative analytical. The populations of this study were patient who at least came 2 times to general polyclinic in RSISA Semarang with sampling method using purposive sampling. Total sample of this study were 125 respondents. Data were collected using a questionnaire with structured question and measurement using Likert 1-5 scale. Data then analyzed using SEM with smartPLS 2.0 software.

Results showed that service quality and customer value gave a significant and positive influence toward patient's satisfaction. The satisfaction itself gave a positive and significant influence toward patient's intention to revisit. Patient's satisfaction that can be explained by service quality and customer value was 45,3\%, and patient's intention to revisit that can be explained by service quality, customer value, and patient's satisfaction was 45,0\%.

Declining trend of total patient who revisit was due to unmeet expectations patient on patient's care in general polyclinic, so patient's satisfaction became unpotimal. Hospital management need to increase patient's satisfaction by always providing service excellent like accuracy of service schedules, availability of information about the right service, and a consistency of workers to polite, greets, and smile to patients so patient's satisfaction will increase and patient's intention to revisit in general polyclinic of RSISA Semarang can increase too.

Keywords : Service Quality, Customer Value, Patient's Satisfaction, Patient's Intention to Revisit

References : $13(1996-2015)$

\section{Pendahuluan}

Kepuasan pasien sebagai pengguna jasa merupakan salah satu indikator dalam menilai mutu jasa pelayanan. Kepuasan yang tinggi akan menunjukkan keberhasilan dalam memberikan pelayanan yang bermutu. Jika kunjungan yang dilakukan mampu memenuhi kebutuhan dan memberikan kepuasan serta manfaat yang besar, maka terjadi kunjungan ulang di masa depan. ${ }^{1}$

Rumah sakit di Jawa Tengah pada tahun 2013, menurut data kepemilikan rumah sakit di Jawa tengah RSU berjumlah 193 yang terdiri dari 131 rumah sakit swata, 62 lainnya adalah rumah sakit pemerintah yang terdiri dari pemerintah pusat, pemerintah propinsi, kota/kabupaten, TNI/POLRI dan BUMN. Dengan demikian persaingan rumah sakit semakin ketat dan diperlukan suatu pengelolaan rumah sakit yang dapat memenuhi kebutuhan kesehatan penduduk Jawa Tengah. ${ }^{2}$

Periode tahun 2010-2013 jumlah kunjungan total pasien di poli umum RSISA menunjukkan adanya fluktuasi. Tahun 2010 sebesar 4594 naik menjadi 6073 pada tahun 2011 kemudian turun menjadi 4484pada tahun 2012 selanjutnya turun menjadi 4399 pada tahun 2013. Begitu juga tren kunjungan pasien lama di poli umum pada periode tahun 2010-2013 mengalami penurunan, sebaliknya kunjungan pasien baru relatif stabil. Prosentase jumlah kunjungan pasien lama di poli umum RSISA pada periode tahun 2010-2013 terjadi penurunan sebesar $6 \%$ yakni dari $81,1 \%$ pada tahun 2010 menjadi $75,1 \%$ pada tahun 2013 . Hal ini menunjukkan belum optimalnya pelayanan di poli umum rawat jalan yang dapat berasal dari produk jasa atau kualitas jasa atau proses penyampaian produk jasa dan pada sistem output pelayanan di poliumum RSISA Semarang. ${ }^{3}$

Tujuan penelitian ini yaitu menganalisis secara keseluruhan pengaruh kualitas jasa dan nilai pelanggan terhadap minat kunjungan ulang melalui kepuasan pasien rawat jalan di poliumum RSISA Semarang.

\section{Metode Penelitian}

Penelitian ini merupakan penelitian explanatory dengan pendekatan waktu cross sectional metode analisis kuantitatif. Populasi penelitian adalah pasien rawat jalan di poli umum RSISA Semarang, sedangkan subyeknya adalah pasien poli umum yang telah datang dan berobat minimal 2 kali. Data dikumpulkan dengan teknik Non Probability Sampling. Jumlah sampel sebanyak 125 orang responden dengan cara pengambilan sampel menggunakan Purposive Sampling. Data dikumpulkan, menggunakan wawancara dan kuesioner dengan item pertanyaan terstruktur dengan pengukuran skala Likert 1-5.

Kualitas Jasa diukur melalui 5 dimensi yaitu Keandalan (A), Daya Tanggap (D), Jaminan (J), Empati (E) dan Bukti Fisik (B). Nilai Pelanggan diukur melalui 4 dimensi terdiri dari Nilai Emosional (NE), Nilai Sosial (NS), Nilai Kualitas (NK) dan Nilai Biaya (NB). Kepuasan diukur melalui indikator: Kepuasan Pelayanan (KP1), Kepuasan Informasi (KP2), Kepuasan Fasilitas Medik (KP3) dan Kepuasan Biaya (KP4). Minat 
Kunjungan Ulang diukur melalui indikator: Selalu berobat kembali (MKU1), Tidak tertarik berobat di RS lain (MKU2), Merekomendasi ke orang lain
(MKU3) dan Memakai unit pelayanan lain di RSISA (MKU3). Bangun model penelitian ini sebagai berikut:

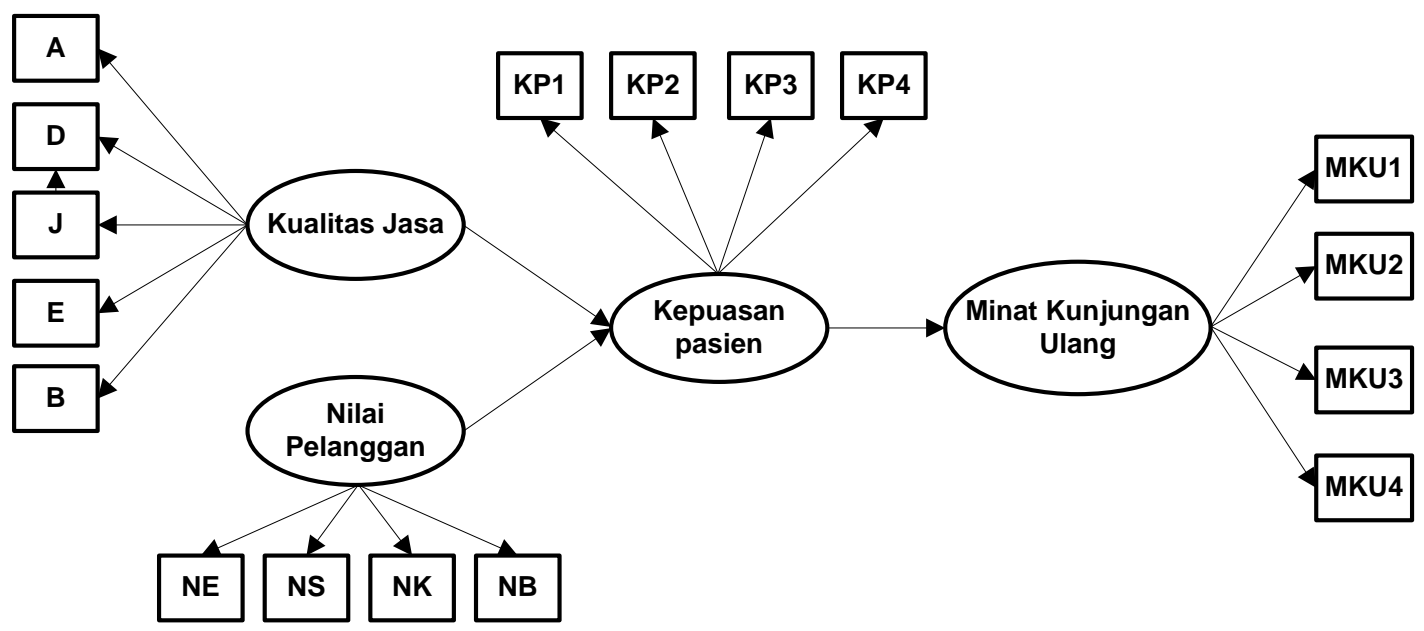

Gambar 1.1. Bangun Model Penelitian

Analisis data penelitian menggunakan analisis deskriptif untuk menggambarkan karakteristik responden dan deskripsi tanggapan responden. Sedangkan analisis interferensial dengan SEM (Structure Equation Modelling) program SmartPLS (Partial Least Square) 2.0 untuk mengetahui hubungan variabel -variabel penelitian.

\section{Hasil}

\section{Analisis Deskriptif}

Berdasarkan hasil penelitian yang dilakukan terhadap 125 orang karakteristik responden dapat dijelaskan bahwa mayoritas responden berjenis kelamin laki-laki 50,4\%, rentang usia antara 2140tahun 42,4\%, alamat di Kodya Semarang 62,3\%, pendidikan SLTA $36,8 \%$, karyawan swasta $32 \%$, pengeluaran perbulan kurang dari $\mathrm{Rp} 2.000 .000$, sebanyak $50,4 \%$, berobat sebagai pasien umum $68,8 \%$, dan alasan berobat atas kesadaran sendiri sebesar 65,6\%.

Rerata tanggapan responden terhadap Kualitas Jasa yaitu 3.95. Dari kelima dimensi Kualitas Jasa yang mempunyai skor diatas rerata adalah Daya Tanggap (D), Jaminan (J), dan Bukti fisik (B).
Sedangkan dimensi Keandalan (A) dan Empati (E) dibawah rerata. Rerata tanggapanresponden terhadap Nilai Pelanggan yaitu 3.87, dari keempatdimensi Nilai Pelanggan yang diatas rerata: Nilai Emosional (NE), Nilai Kualitas (NK), Nilai Biaya (NS), sedangkan Nilai Sosial (NS) dibawah rerata. Rerata tanggapanresponden terhadap Kepuasan yaitu 3.97. Indikator kepuasan diatas rerata: KP3 dan KP4 dan indikator dibawah rerata: KP1 dan KP2. Rerata tanggapan responden Minat Kunjungan Ulang adalah 3.84, indikatorindikator diatas rerata: MK1, MK3 dan MK4, dan indikator dibawah rerata MK2.

\section{Analisis Inferensial}

Menurut Chin pelaporan hasil analisis PLS menggunakan dua tahap yang disebut two step approach. Tahap pertama difokuskan untuk hasil dari model pengukuran (Outher Model) dan tahap kedua difokuskan untuk hasil dari model struktural (Inner Model). ${ }^{17}$ Penelitian ini menggunakan program Smart PLS 2, didapatkan model pengukuran (Outher Model) seperti pada gambar 1.2, model hasil penelitian dikatakan model sudah fit sehingga tidak diperlukan modifikasi model.

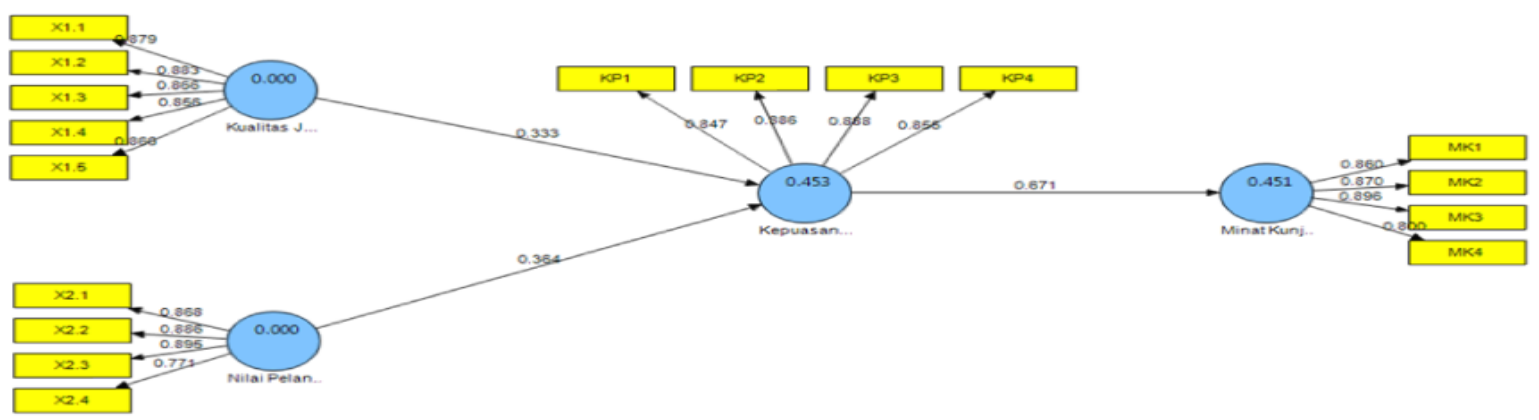

Gambar 1.2. Model Pengukuran Hasil Penelitian 
A. Pengukuran Outher Model

Tabel 1.1. Uji Convergent Validity

\begin{tabular}{lcc}
\hline \multicolumn{1}{c}{ Variabel } & Indikator & Outer Loading \\
\hline Kualitas Jasa & A & 0.87945 \\
& D & 0.88263 \\
J & 0.86602 \\
Nilai Pelanggan & E & 0.85596 \\
& B & 0.86560 \\
Nepuasan Pasien & NS & 0.86790 \\
& NK & 0.88582 \\
& NB & 0.89513 \\
KP1 & 0.77114 \\
& KP2 & 0.84699 \\
& KP3 & 0.88614 \\
& KP4 & 0.88773 \\
& MK1 & 0.85643 \\
& MK2 & 0.85988 \\
& MK3 & 0.87011 \\
& MK4 & 0.89570 \\
\hline
\end{tabular}

1) Convergent Validity

Pengukuran convergent validity digunakan nilai outer loading. Ukuran refleksif individual dikatakan tinggi jika berkorelasi lebih dari 0,70 dengan konstruk yang diukur. Dari tabel 1.1 dijelaskan nilai outher loading indikator-indikator yang bermanifestasi terhadap variabel penyusunnya pada penelitian ini lebih dari 0,7 sehingga dikatakan bahwa indikator-indikator variabel penelitian memenuhi syarat validitas.

2) Discriminant Validity

Tabel 1.2. Hasil Average Variance Extracted (AVE)

\begin{tabular}{lcc}
\multicolumn{1}{c}{ Variabel } & AVE & Akar AVE \\
\hline Kualitas Jasa & 0.75688 & 0.86999 \\
Nilai Pelanggan & 0.73346 & 0.85642 \\
Kepuasan Pasien & 0.75604 & 0.86951 \\
Minat Kunjungan & 0.73463 & 0.85710 \\
Ulang & \\
\hline
\end{tabular}

Evaluasi discriminant validity selain menggunakan nilai cross loading dapat juga dilihat dari nilai akar Average Variance Extracted (AVE) untuk setiap konstruk dan membandingkannya dengan korelasi antar konstruk. Tabel 1.2 menunjukan bahwa nilai seluruh akar AVE > 0,5, sehingga dapat disimpulkan semua indikator tiap-tiap konstrak dalam model yang diestimasi memenuhi kriteria validitas. Menurut Fornell \& Locker dalam Ghozali (2015), model memiliki discriminant validity yang baik, jika akar AVE untuk setiap konstruk dalam model lebih tinggi dari korelasi antara konstruk tersebut dengan konstruk lainnya. Dari tabel 1.3 nilai akar AVE lebih tinggi dari dari nilai korelasi antar variabel sehingga dapat dijelaskan variable-variabel penelitian memenuhi syarat validitas.

Tabel 1.3. Nilai Korelasi Antar Kontruks

\begin{tabular}{lcccc}
\hline & Kualitas Jasa & $\begin{array}{c}\text { Nilai } \\
\text { Pelanggan }\end{array}$ & $\begin{array}{c}\text { Kepuasan } \\
\text { Pasien }\end{array}$ & $\begin{array}{c}\text { Minat Kunjungan } \\
\text { Ulang }\end{array}$ \\
\hline Kualitas Jasa & 1 & & & \\
\hline Nilai Pelanggan & 0.866891 & 1 & & \\
\hline Kepuasan Pasien & 0.648281 & 0.652374 & 1 & 1 \\
\hline Minat Kunjungan Ulang & 0.474214 & 0.502393 & 0.671323 & \\
\hline
\end{tabular}

3) Composite Reliability

Tabel 1.4 menunjukkan bahwa nilai composite reliability untuk semua kontruks/variabel semuanya lebih dari 0,7 . Dengan demikian pada model penelitian, masing-masing variabel penelitian memenuhi reliabilitas. 
Tabel 1.4. NilaiComposite Reliability

\begin{tabular}{lc}
\hline Kontruks & $\begin{array}{l}\text { Composite } \\
\text { Reliability }\end{array}$ \\
\hline Kualitas Jasa & 0,939628 \\
Nilai Pelanggan & 0,916460 \\
Kepuasan Pasien & 0,925322 \\
Minat Kunjungan Ulang & 0,917044 \\
\hline
\end{tabular}

B. Pengukuran Model Struktural (Inner Model)

Evaluasi pertama pada inner model dilihat dari nilai R-Square atau koefisien determinasi. Evaluasi ini fungsinya adalah melihat nilai signifikansi dari variabel laten dengan menggunakan $R$-square $\left(\mathrm{R}^{2}\right)$. Berdasarkan table 1.4 dapat di interpretasikan sebagai berikut :

a. Kepuasan pasien yang dapat dijelaskan oleh konstruk nilai pelanggan dan kualitas jasa sebesar 45,3\% sedangkan $54,7 \%$ dijelaskan oleh variabel lain diluar yang diteliti.

b. Minat kunjungan Ulang yang dapat dijelaskan oleh konstruk kepuasan pasien sebesar $45 \%$ sedangkan $55 \%$ dijelaskan oleh variabel lain diluar yang diteliti.

Tabel 1.5. Nilai R-Square

\begin{tabular}{ll}
\hline Kontruks & R-Square \\
\hline Kepuasan pasien & 0,453143 \\
Minat kunjungan ulang & 0,450675 \\
\hline
\end{tabular}

Goodness of fit pada model PLS dapat diketahui dari nilai $Q^{2}$. Nilai $Q^{2}$ memiliki arti yang sama dengan koefisien determinasi (Rsquare $/ \mathrm{R}^{2}$ ) dalam analisis regresi. Semakin tinggi $\mathrm{Q}^{2}$, maka model dapat dikatakan semakin fit. Dari Tabel1.5 di atas, $\mathrm{Q}^{2}$ dihitung dengan rumus $1-\left(1-\mathrm{R}_{1}{ }^{2}\right)\left(1-\mathrm{R}_{2}{ }^{2}\right)$. Dari hasil penelitian, niali $\mathrm{Q}^{2}$ sebesar 0,69960 artinya tingkat variasi perubahan model yang dapat dijelaskan oleh variabel kualitas jasa, nilai pelanggan, kepuasan pasien dan minat kunjungan ulangsebesar 69,96\%.

Selanjutnya adalah uji kausalitas yang digunakan untuk menguji hipotesis penelitian untuk melihat hubungan dan signifikasi variabel penelitian seperti pada tabel berikut ini :

Tabel 1.6. Nilai Original Sample dan t-Statistics

\begin{tabular}{lcccc}
\hline & $\begin{array}{c}\text { Original } \\
\text { Sample }(O)\end{array}$ & $\begin{array}{c}\text { Sample } \\
\text { Mean }(M)\end{array}$ & $\begin{array}{c}\text { Standard } \\
\text { Error }(\text { STERR })\end{array}$ & $\begin{array}{c}t \text {-Statistics } \\
(\mid \text { OSTERR } \mid)\end{array}$ \\
\hline Kualitas Jasa $\rightarrow$ Kepuasan Pasien & 0,332976 & 0,345921 & 0,160551 & 2,073952 \\
$\begin{array}{l}\text { Nilai Pelanggan } \rightarrow \text { Kepuasan Pasien } \\
\begin{array}{l}\text { Kepuasan Pasien } \rightarrow \text { Minat } \\
\text { Kunjungan Ulang }\end{array}\end{array}$ & 0,363720 & 0,341798 & 0,158706 & 2,291789 \\
\hline
\end{tabular}

Pengujian hipotesis dilakukan dengan ditolak dan hipotesis penelitian diterima. Dari menggunakan t-statistics. Apabila nilai t- tabel 1.7 terlihat hipotesis pada penelitian ini statistics $\geq$ nilait-tabel $(1,96)$ maka Ho seluruhnya diterima.

Tabel 1.7. Hasil Pengujian Hipotesis

\begin{tabular}{cccccc}
\hline Hipotesis & Koefisien Path & Taraf signifikansi & t-tabel & t-statistik & Hasil \\
\hline 1 & 0.332976 & $5 \%$ & 1,96 & 2.073952 & Diterima \\
2 & 0.363720 & $5 \%$ & 1.96 & 2.291789 & Diterima \\
3 & 0.671323 & $5 \%$ & 1.96 & 10,18228 & Diterima \\
\hline
\end{tabular}

Hipotesis kesatu yaitu terdapat pengaruh kualitas jasa terhadap kepuasan pasien. Hasil penelitian nilai koefisien path sebesar 0,332976 , taraf signifikansi $5 \%(\mathrm{t}=1.96)$, dan t-statistic 2,291789. Diinterpreasikan Kualitas Jasa berpengaruh positif dan signifikan terhadap kepuasan pasien, artinya semakin 
baik kualitas jasa yang diberikan, maka meningkat pula kepuasan pasien.

Hipotesis kedua yaitu terdapat pengaruh nilai pelanggan terhadap kepuasan pasien. Hasilpenelitian nilai koefisien path sebesar 0,363720 , taraf signifikansi $5 \%(t=1.96)$, dan $\mathrm{t}$-statistic 2,291789. Disimpulkan bahwa Nilai Pelanggan berpengaruh positif dan signifikan terhadap kepuasan pasien, artinya semakin tinggi nilai pelanggan yang didapat pasien , maka meningkat pula kepuasan pasien.

Hipotesis ketiga yaitu terdapat pengaruh kepuasan pasien terhadap minat kunjungan ulang. Hasil penelitian nilai koefisien path sebesar 0,671323, taraf signifikansi $5 \% \%(\mathrm{t}$ $=1.96)$ dan t-statistic 9,6737 dapat disimpulkan Kepuasan pasien berpengaruh positif dan signifikan terhadap minat kunjungan ulang, artinya semakin tinggi kepuasan pasien semakin meningkat pula minat kunjungan ulang pasien.

\section{Pembahasan}

Kepuasan merupakan evaluasi jangka panjang dari kualitas jasa.Pendekatan model riset pemasaran dengan SERQUAL yang dibangun oleh Pasuraman et al menekankan pada perbandingan persepsi antara kenyataan yang diterima dengan layanan yang diharapkan. ${ }^{5}$ Peningkatan kualitas jasa di poliumum RSISA Semarang akan meningkatkan pula kepuasan pelanggan artinya pasien berpersepsi produk jasa makin berkualitas. Manajemen kualitas diperlukan untuk menjamin kualitas jasa pelayanan yang mampu memenuhi kebutuhan dan harapan pelanggan. Peryaratan dan kebutuhan serta umpan balik dari pelanggan menjadi dasar bagi pengembangan manajemen kualitas jasa RSISA.

Nilai yang diterima pasien bisa mengarahkan perasaan kepuasan secara keseluruhan. Penyajian nilai yang unggul bagi pasien merupakan prasyarat yang nyata untuk kepuasan pelanggan. Pasien membentuk harapan dari nilai lebih suatu kinerja pelayanan dan bertindak berdasarkan besarnya manfaat yang diterima dengan dibatasi harga, waktu, tenaga dan biaya psikologis. ${ }^{1}$ Semakin tinggi persepsi nilai yang dirasakan pasien poliumum RSISA semakin tinggi pula kepuasan pasien.
Apabila kepuasan pasien terhadap jasa di bawah apa yang diharapkan, maka pasien akan kehilangan minat terhadap penyedia jasa. Kepuasan merupakan evaluasi dari pengalaman pelayanan yang diterima sebelumnya dan memberi dampak terhadap perilaku pelanggan akan produk jasa tersebut. Pasien yang merasakan positif terhadap pelayanan jasa akan mengembangkan sikap loyal dan mendukung penyedia jasa tersebut seperti berkata positif akan produk jasa, merekomendasikan teradap orang lain. ${ }^{16}$ Kepuasan pasien poliumum RSISA merupakan evaluasi secara keseluruhan selama menggunakan pelayanan di poliumum. Apabila kepuasan yang dirasakan tinggi maka akan meningkatkan minat kunjungan ulang berobat di poliumum RSISA.

Kualitas jasa dan nilai pelanggan poliumum RSISA berpengaruh positif dan signifikan terhadap minat kunjungan ulang melalui kepuasan pasien. Semakin tinggi kualitas pelayanan dan nilai pelanggan semakin tinggi pula kepuasan yang didapat pasien dan memberikan dampak semakin tinggi pula minat kunjungan ulang pasien

\section{Kesimpulan}

Berdasarkan hasil penelitian ini disimpulkan: (1) Terdapat pengaruh positif dan signifikan Kualitas Jasa terhadap Kepuasan Pasien di poliumum RSISA Semarang. Hasil ini membuktikan semakin baik Kualitas Jasa yang diterima pasien semakin meningkat pula kepuasan yang dirasakan pasien. (2) Terdapat pengaruh positif dan signifikan nilai pelanggan terhadap kepuasan pasien di poliumum RSISA Semarang. Hasil ini membuktikan responden merasa puas karena tingginya nilai pelanggan yang didapatkan dari pelayanan di poliumum RSISA Semarang, artinya semakin besar manfaat yang diterima pasien semakin memperkuat kepuasan. (3) Terdapat pengaruh positif dan siginifikan Kepuasan Pasien terhadap Minat Kunjungan Ulang di poliumum RSISA Semarang. Hasil penelitian ini membuktikan semakin tinggi kepuasan pasien semakin meningkat pula minat kunjungan ulang untuk berobat kembali di RSISA. 


\section{DAFTAR PUSTAKA}

1. Lupiyoadi, R. Manajemen Pemasaran Jasa Berbasis Kompetensi. Edisi 3. Jakarta; Penerbit Salemba Empat. 2013.

2. Jateng.bps.go.id/linkTabelStatis/view/id/1 092; diunduh tanggal 19 Maret 2015 pukul 17.45 WIB.

3. Tjiptono, F. Pemasaran Jasa Prinsip, Penerapan dan Penelitian. Yogyakarta: 2014.

4. Kotler, P. and K. L., Kelller. Marketing Managemen. $14^{\text {th }}$ ed. Prentice Hall International. Inc; 2012.

5. Oliver, Ricard L. Whence Consume Loyality. Journal of Marketing.1999; (63); 33-34.

6. Spreng, R. A. S. B, MacKenzie and R. W., Olshavsky. A reexamination of the determinants of consumer satisfaction. Journal of Marketing.1996; 60(3); 15-22.

7. Dabholkar,P.C., D. Shepherd, and D.I., Thorpe. A Comphrehensive framework for Service Quality: An Investigation of Critical Conceptual and Measurement Issues Through a Longitudinal Study. Journal of Retailing. 2000; 76(2); 139174.

8. Woodruff, R.B. Costumer value: The next source for advantage. Journal of the Academy of Marketing Science. 1997; 25(2); 183-198.

9. Farida, N. Analisis Model Kepuasan terhadap Pembelian Ulang. Jurnal Dinamika Manajemen. 2014; 5(2); 200208.

10. Sweeney, J. C. and G. N. Soutar .Consumer Perceived Value: The development of multiple item scale. Journal of Retailing. 2001; 77; 203-220.

11. Woro, M. Pengaruh Nilai Pelanggan dan Kualitas Layanan terhadap Loyalitas Pelanggan, melalui Kepuasan Pelanggan pada Pelanggan Bus Efisiensi. Jurnal Administrasi Bisnis. 2013; 2(1); 64-75.
12. Saidani, B. Pengaruh Kualitas Produk Dan Kualitas Layanan Terhadap Kepuasan Konsumen dan Minat Beli Pada Ranch Market. Jurnal Riset Manajemen Sains Indonesia (JRMSI). 2010; 3(1); 115.

13. Gozhali, I. Structural Equation Modeling: Teori, Konsep Dan Aplikasi Dengan Program Smart PLS 3.0. Semarang; Badan Penerbit Undip; 2015. 